\title{
Vegetative organ anatomy of Ianthopappus corymbosus Roque \& Hind (Asteraceae-Mutisieae)
}

\author{
GLADYS F.A. MELO-DE-PINNA ${ }^{1,3}$ and NANUZA L. MENEZES ${ }^{2}$
}

(received: May 9, 2001; accepted: August 14, 2002)

\begin{abstract}
Vegetative organ anatomy of Ianthopappus corymbosus Roque \& Hind (Asteraceae-Mutisieae). A study on the vegetative organ anatomy of Ianthopappus corymbosus was conducted in order to provide a basis for comparison with the genus Richterago, since this species had been previously included in that genus. The anatomical characters of $I$. corymbosus that support its exclusion from the genus Richteragon are: epithelial cell organization of adventitious root secretory canals, non-glandular trichomes, and presence of cortical vascular bundles in the stem. In Ianthopappus corymbosus, the underground system consists of rhizophore from which adventitious roots branch off. The subapical meristem of the adventitious root revealed that the ground meristem forms the inner layer which in a meristematic phase, forms $2 / 3$ of the cortex. This layer will differentiate in the endodermis, with Casparian strips, and is referred to as meristematic endodermis. Endodermic secretory canals, limited by four epithelial cells, appear in the region adjacent to the primary phloem.
\end{abstract}

RESUMO - (Anatomia dos órgãos vegetativos de Ianthopappus corymbosus Roque \& Hind (Asteraceae-Mutisieae). Estudo sobre a anatomia dos órgãos vegetativos de I. corymbosus foi realizado para servir como base na comparação com o gênero Richterago, o qual incluia anteriormente a espécie em questão. Os caracteres anatômicos de $I$. corymbosus que podem ser utilizados para a exclusão da espécie do gênero Richterago são: a organização das células epiteliais dos canais secretores das raízes adventícias, o tipo de tricoma tector e a presença de feixes vasculares corticais no caule. O sistema subterrâneo de Ianthopappus corymbosus consiste de um rizóforo, a partir do qual originam-se raízes adventícias. O meristema sub-apical da raiz adventícia revelou que o meristema fundamental origina a camada interna, a qual em fase meristemática, origina 2/3 do córtex. Esta camada irá se diferenciar na endoderme com estrias de Caspary e é referida como endoderme meristemática. Canais secretores endodérmicos delimitados por quatro células epiteliais foram observados na região adjacente ao floema primário.

Key words - Amyliferous sheath, Asteraceae, meristematic endodermis, pericycle fibers, proendodermis

\section{Introduction}

The genus Ianthopappus, recently described by Roque \& Hind (2001), includes a single species (I. corymbosus Roque \& Hind) and is hypothesized as the sister-group of Richterago. Ianthopappus corymbosus had been previously included in genus Richterago (R. corymbosa).

Studies conducted on the vegetative organ anatomy of species of the genus Richterago show a rather uniform anatomical organization, e.g. secretory canals and laticifers in roots, cortical vascular bundles absent in stems and glandular and non-glandular trichomes in leaves (Melo-de-Pinna 2000). Previous results by Melo-de-Pinna (2000) led to the development of the

\footnotetext{
1. Universidade Federal de Pernambuco, Centro de Ciências Biológicas, Departamento de Botânica, Av. Prof. Moraes Rêgo s/n, 50372-970 Recife, PE, Brazil.

2. Universidade de São Paulo, Instituto de Biociências, Departamento de Botânica, Rua do Matão, Travessa 14, 05422-970 São Paulo, SP, Brazil.

3. Corresponding author: gfmelopinna@aol.com
}

present study, which offers the anatomical characterization of Ianthopappus corymbosus, and compares the results with those available for the species of Richterago.

\section{Materials and methods}

Material was collected at Ibirapuitã Biological Sanctuary, municipality of Alegrete, State of Rio Grande do Sul. Specimens of Ianthopappus corymbosus were taken from a small population growing in sandy, flooded soil. Voucher specimes are deposited in the herbarium of the Universidade de São Paulo, São Paulo (SPF, Roque et al. 462).

Segments of the aerial stem, underground stem, adventitious roots, and leaves (apex, middle and base) were fixed in FGAA (Lersten \& Curtis 1988). An illustration of the habit of the plant was prepared before the material was sectioned. After dehydration in ethylic series, parts of the different organs were kept in ethanol $70 \%$ and later processed for inclusion and infiltration in paraffin (Johansen 1940). Cross-sections (freehand) were made from the remaining material. In both cases, double staining with astra blue and basic fuchsin was used, according to the methodology described by Kraus et al. (1998). 
The leaf blade was "scraped" to provide trichomes. After diafanization, this material was stained with both astra blue and basic fuchsin (Kraus et al. 1998). The following reagents were used in the histochemical tests: Sudan IV (Sass 1951); 10\% ferric chloride (Johansen 1940), and lugol (Berlyn \& Miksche 1976), for lipidic substances, phenolic substances and starch, respectively.

\section{Results}

Ianthopappus corymbosus is a sub-arbustive species, and some plants grow up to 1 meter tall. The underground system consists of a thick stem system from which adventitious roots and aerial stems branch off (figure 1). All the roots observed are adventitious. No root type that might have resulted from the development of primary roots was found.

Adventitious roots - The region close to the meristematic zone (figure 2) shows a protoderm made up of elongated cells, in the organ perpendicular axis, and a hypodermis that is already individualized.

Figure 3 represents a cross-section of the region during early differentiation, with derivatives of a meristematic endodermis or proendodermis. The successive divisions originate more than $2 / 3$ of the cortex, whose cells are radially arranged. During this phase, the vascular system is beginning to differentiate, and some elements of primary phloem can already be observed. Secretory canals are found in distal regions of the subapical meristem, adjacent to primary phloem (figure 4). These canals are limited by four epithelial cells, and in the section displayed in figure 4, two of these cells limit two canals. A longitudinal section, represented in figure 5 , shows the cavity of a secretory canals limited by epithelial cells.

In secondary structure, the adventitious root has a uniseriate epidermis with " $\mathrm{O}$ " wall thickening. These epidermal cells, actually sclereids, may have projections, thus becoming short trichomes (figure 6), especially at the base of the root. Under such epidermis there is a hypodermis made up of cells with thickened anticlinal and external periclinal walls. Figure 7 shows sclereids in the external region of the cortex. The total differentiation of the vascular system into secondary xylem and phloem results in a relative increase in the lumen of secretory canals, and in the collapse of two epithelial cells that limit adjacent canals (figure 8). The endodermis is differentiated, with Casparian strips, and wall thickening in some cells, mainly at the base of the root. The pericycle is bi or triseriate. As the organ becomes thicker, the primary phloem cells collapse. The medullary region is wide and compact, lacking large intercellular spaces.

Rhizophore - A subhypodermal phellogen originates the peridermis (figures 9-12), including divisions of hypodermal cells (continuous with root hypodermis). In regions where the epidermis is still visible (figure 11), the epidermal cells, like those in the root, have thickened walls. Due to the organ irregularity, the cortex contains 5 to 20 cell layers, with clear intercellular spaces. The secondary phloem is wide, its parenchyma rays are perfectly distinguished. The xylem has vessel elements with larger diameters, arranged in a unique ring, as shown in figure 13, and another band (still inner) made up of elements with smaller diameter.

Aerial Stem - Cross-section of the aerial stem shows four bulges that correspond to ribs. The uniseriated epidermis consists of small papillose cells with periclinal and anticlinal thickened walls. It also has multicellular nonglandular trichomes, with lignified cell walls as shown in figures 14 and 15 . Two or three collenchyma cell layers are found below the epidermis (figure 16). Four collateral cortical vascular bundles are present (figure 17), distinguished from leaf traces by xylem and phloem position; while in the cortical vascular bundles the xylem is outside the phloem, in leaf traces xylem is oriented to the organ axis. Although endodermis (figures 18-20), that limits the vascular cylinder, does not have Casparian strips, it can be detected by the presence of phenolic substances. The pericycle is multiseriated, with 6 to 10 cells layers in perimedullary region and in the region adjacent to primary phloem, it is represented by fibers (figures 18-19). The endodermis follows leaf traces, together with pericycle fibers, surrounding vascular system (figure 20). The pericycle, still parenchymatic, also follows each leaf trace internally (figure 20). It is only differentiated by fibers, in leaf petiole (figure 24). Interfascicular cambium originates from pericycle (figure 18-19). The pith is wide and fistulous, its core is formed from a cavity resulting from cell lysis (figure 17).

The basis of a stem bud is seem near the node (figure 21). A more detailed view (figure 22) shows distinguished protoxylem poles. Leaf primordium of another stem bud is shown in figure 23 .

Petiole and leaf blade - From the anatomical viewpoint, the petiole (figure 24) and the leaf blade (figures 25-29) have similar traits, such as the presence of larger epidermal cells in adaxial surface than in abaxial surface, and lamellar collenchyma with three to four cell layers (figure 25). They have non-glandular trichomes (figure 26), just like those found in stem.

The petiole has five vascular units. The endodermis 


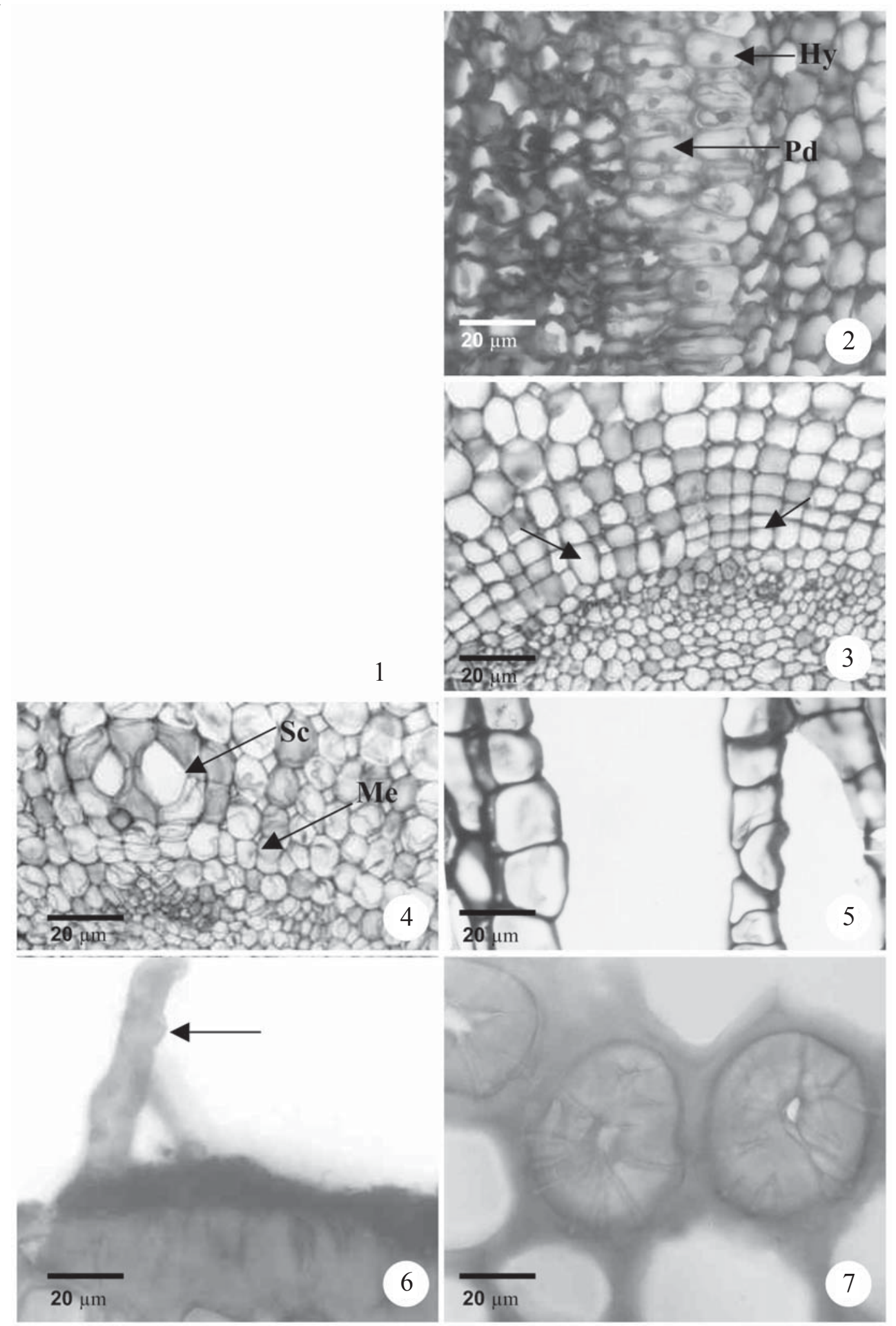

Figures 1-7. 1. Habit of Ianthopappus corymbosus, showing rhizophore (Ry) and adventitious roots (Ar). 2-4. Transversal sections of the meristematic region of adventitious roots. 2. Protodermis (Pd) with elongated cells and hypodermis (Hy). 3-4. Meristematic phase of the endodermis (arrows) showing derivative cells radially arranged. 4. Secretory canals ( $\mathrm{Sc}$ ) originated from the meristematic endodermis (Me). 5. Longitudinal section of the meristematic zone showing secretory canals lumen. 6. Transversal section of adventitious roots in secondary structure showing tricome with wall thickening (arrow).7. Sclereids in external region of the cortex. 

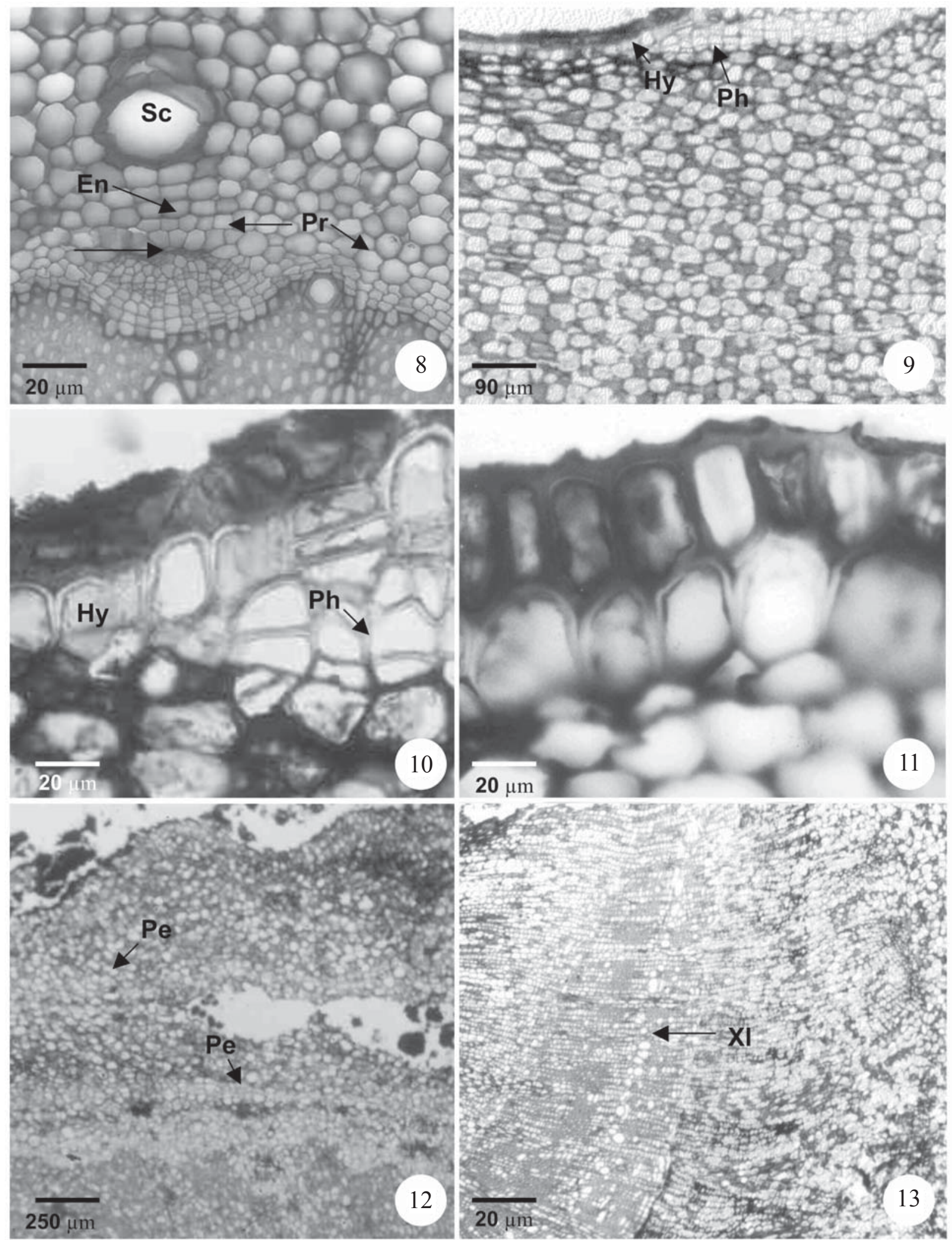

Figures 8-13. Transversal sections of adventitious root and rhizophore. 8. Adventitious root in secondary structure with secretory canals, showing endodermis (En), multiseriate pericycle ( $\operatorname{Pr})$ and primary phloem collapsed cells (arrow). 9-11.Rhizophore showing hypodermis (Hy) and subhypodermal phellogen (Ph). 12. Rhizophore, note enlarging periderm (Pe). 13. Rhizophore showing vessel elements with larger diameters arranged in ring (Xl). 

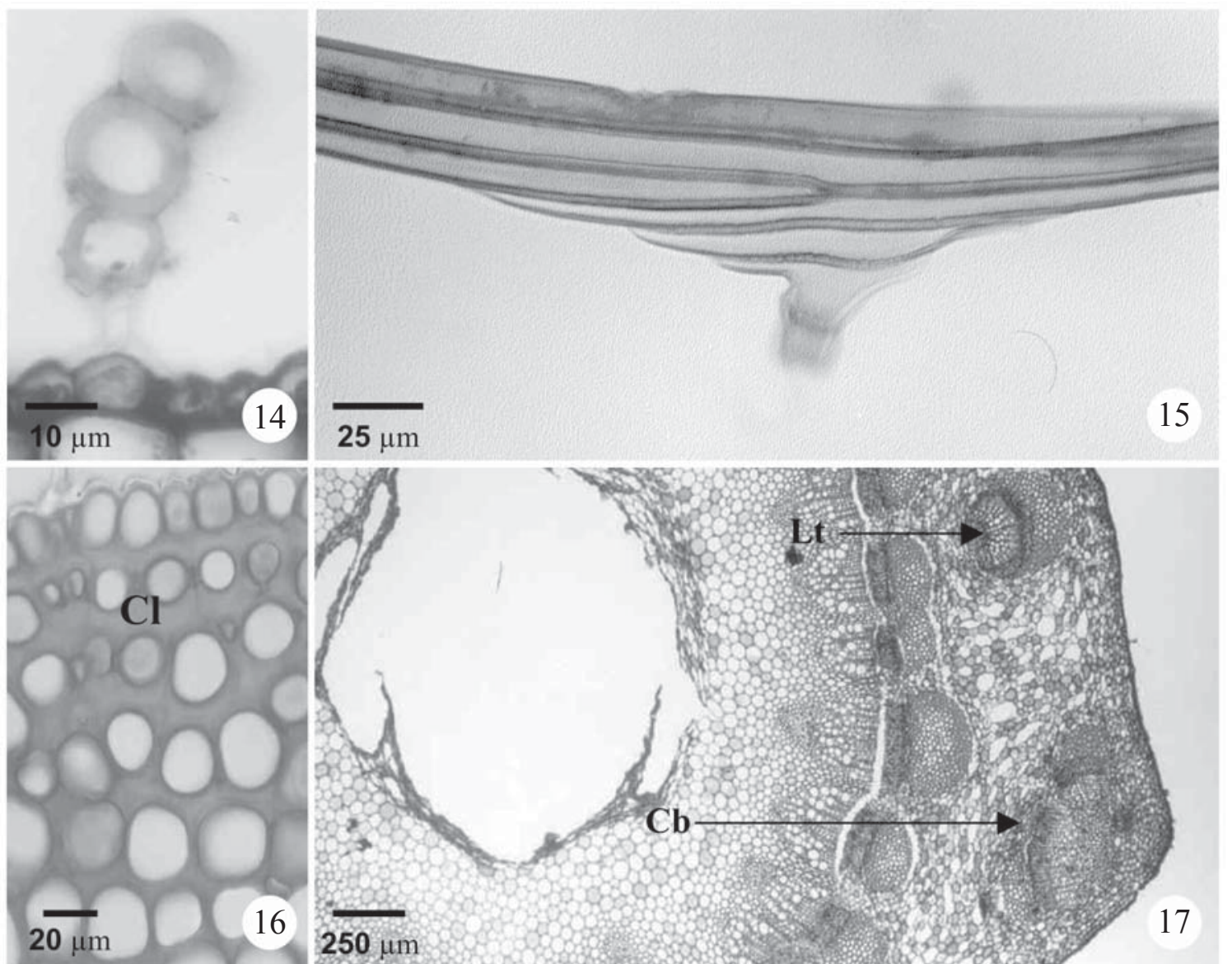

$25 \mu \mathrm{m}$

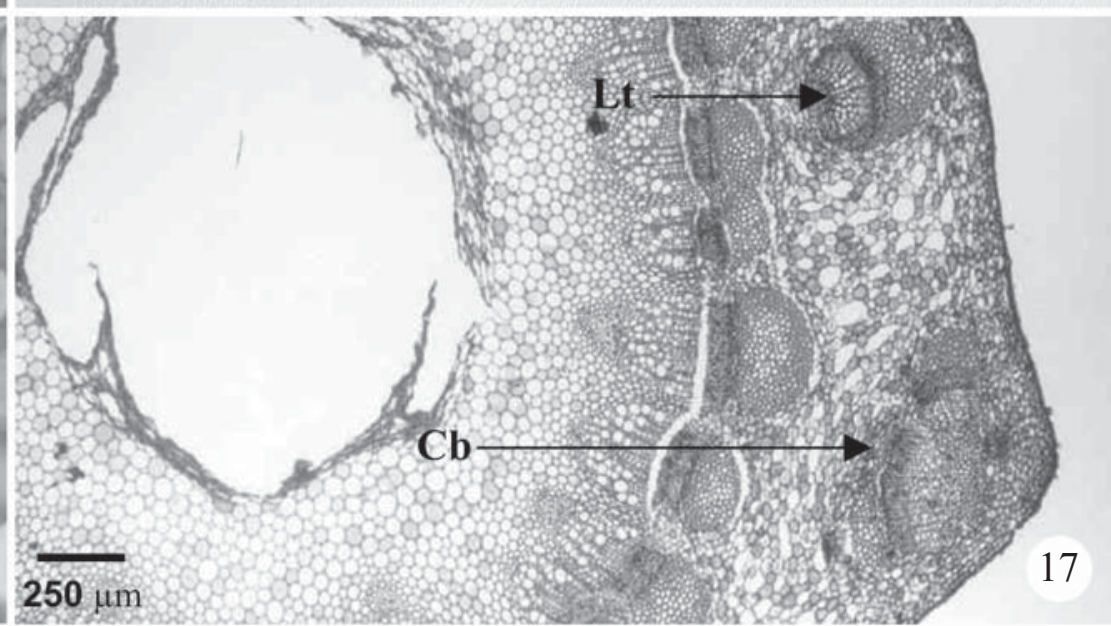

Figures 14-15. Non-glandular trichome with lignified cell walls. 14. Longitudinal section of the trichome. 15. Trichome observed after "scraped" of the leaf blade. 16. Transversal section of the aerial stem showing collenchyma cells layers $(\mathrm{Cl})$. 17. Transversal section of the aerial stem showing cortical vascular bundle $(\mathrm{Cb})$, leaf trace $(\mathrm{Lt})$ and fistulous pith.

surrounds the vascular tissue and pericycle fibers form bands outside primary xylem and phloem region.

At the central vascular unit region, the endodermis clearly involves the vascular unit (figure 25), and is represented in figures 27 and 28 as an amyliferous sheath. The multiseriate pericycle is made up of fibers.

In leaf blade, bilateral mesophyll (figure 25) is made up of three to four layers of palisade parenchyma and the spongy parenchyma is made up of braciform cells. The vascular units of the leaf blade are closer to the abaxial surface, the xylem and phloem are surrounded by the endodermis and by the pericycle fibers, similary to the vascular unit of the midvein. The same figure shows that the epidermal cells of the adaxial surface are larger than those found in the abaxial surface.

\section{Discussion}

Two points in the anatomy of adventitious roots of Asteraceae deserve notice: the presence of meristematic endodermis and of secretory canals. Williams (1947) mentioned the existence of a meristematic phase of the endodermis in the subapical meristem and primary tissues in the roots of vascular plants. In 1954, the same author conducted a study on the secretory canals of Asteraceae roots, which originate from the meristematic endodermis. Hurst (1954 apud Van Fleet 1961) defined as proendodermis the layer which originated part of the cortex, and Van Fleet (1961) emphasized the occurrence of a meristematic phase of the endodermis, as suggested by Williams (1947), synonymyzing proendodermis and meristematic endodermis. More recent studies use the term proendodermis (Mueller 1991, Seago et al. 1999, Seago \& Scholey 1999), but in this study the term meristematic endodermis has been adopted.

According to Williams (1947), who studied 74 species of monocotyledons, 105 of dicotyledons, 11 of pteridophytes and 5 of gymnosperms, in all cases, except for some pteridophytes, the meristematic endodermis originates tissues between the endodermis 

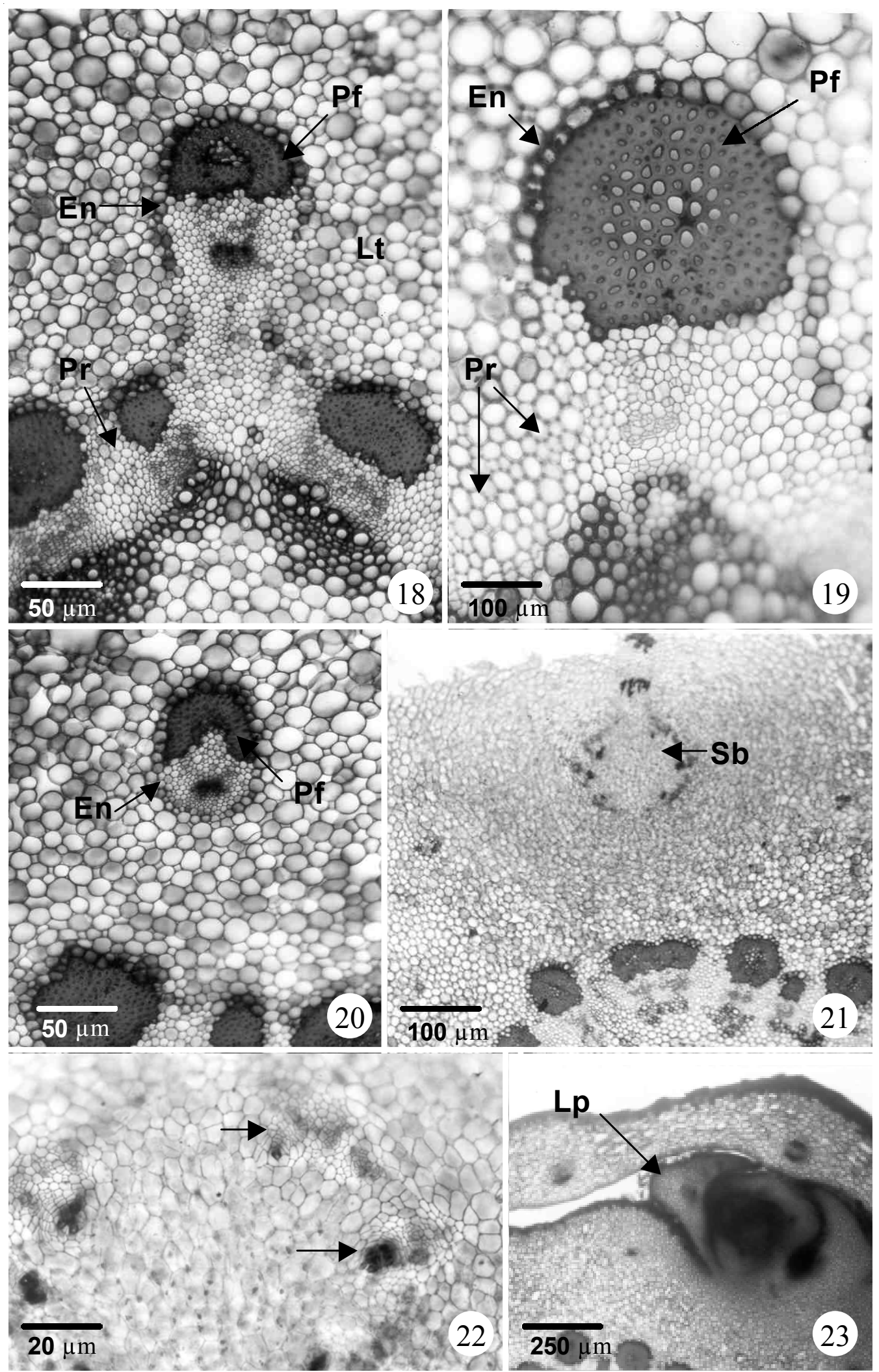

Figures 18-23. Transversal sections of the aerial stem. 18-20. Sequency showing pericycle fibers (Pf) and endodermis (En) surrounding the leaf trace (Lt). Note multiseriate pericycle with parenchyma cells (Pr). 21-22. Stem bud (Sb) near the node showing the vascular bundles (arrows). 23. Stem buds showing a leaf primordium (Lp). 

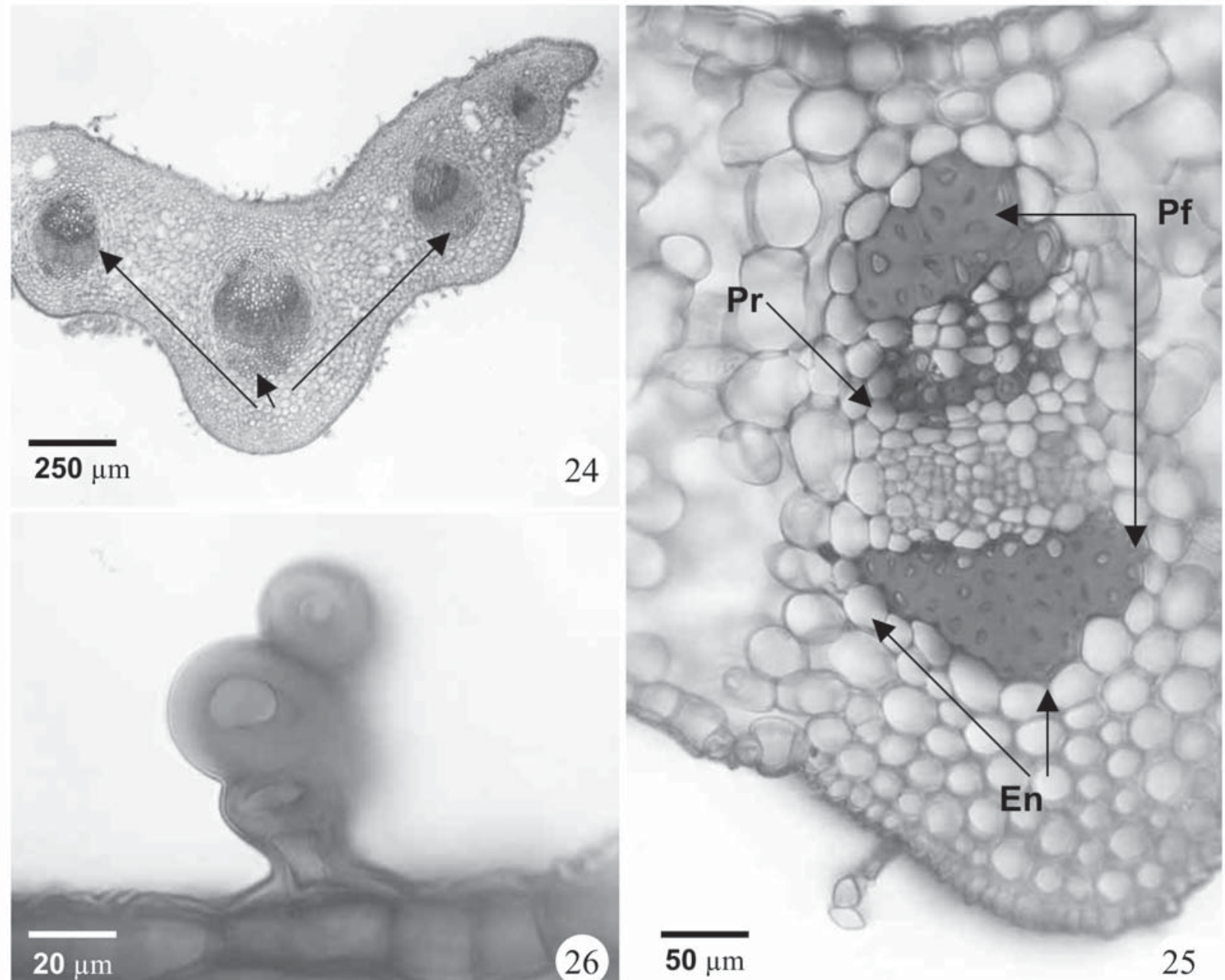

$20 \mu \mathrm{m}$

26
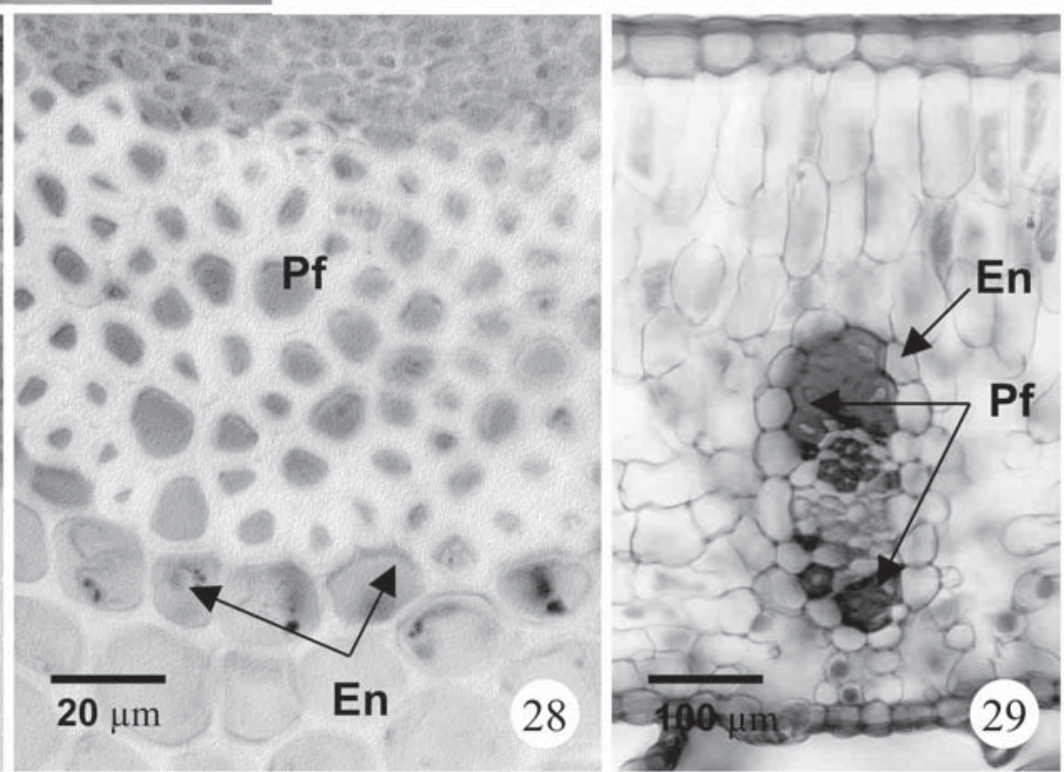

Figures 24-29. 24. Transversal sections of the petiole showing vascular units (arrows). 25-29. Transversal sections of the leaf blade. 25. Vascular units showing pericycle fibers ( $\mathrm{Pf})$, pericycle with parenchyma cells ( $\mathrm{Pr})$ and endodermis $(\mathrm{En})$; note the lamellar collenchyma near the abaxial surface. 26. Non-glandular trichome with lignified cell walls. 27-28. Vascular units showing endodermis as amyliferous sheath (En) and pericycle fibers (Pf). 29. Bilateral mesophyll with vascular units surrounded by pericycle fibers $(\mathrm{Pf})$, and endodermis (En). 
and the hypodermis. In roots of Ianthopappus corymbosus, the meristematic endodermis will originate more than $2 / 3$ of the cortex, and the external part of the cortex will result from hypodermal cell divisions at early differentiation stages. Similarly to the situation observed in I. corymbosus, Seago et al. (1999) mentioned that the "proendodermis originated the mid and inner ground meristem" in roots of Hydrocharis morsus-ranae. In I. corymbosus, as for the species of Richterago (Melo-de-Pinna 2000), only the inner cortex originates from meristematic endodermis.

In this study, the term hypodermis refers to the outer layer of the stem and root cortex, based on Williams (1947), Van Fleet (1961), Barnabas (1996), Seago et al. (1999) and Seago \& Scholey (1999), which showed that besides the same origin, the stem and root hypodermis may also have Casparian strips. Even though, the use of two different terms is unnecessary, authors like Esau (1960) and Fahn (1974) use the term exoderm for the root and hypodermis for the stem.

Several authors have described the presence of secretory canals in leaves, and especially in roots of Asteraceae (Triebel 1885, Col 1899, 1901, 1903, 1904, Solereder 1908, Williams 1947, Metcalfe \& Chalk 1950, Hoehne et al. 1952, Esau 1960, Fahn 1974, Heywood 1978, Bremer 1994) and reports that they are formed from the endodermis (Triebel 1885, Solereder 1908, Tetley 1925, Williams 1954, Luque et al. 1997, Melo-de-Pinna 2000). In Ianthopappus corymbosus, the meristematic endodermis plays a major role in the formation of secretory canals. For Mutisieae, the first study to show the presence of secretory canals in adventitious roots was on species of Richterago (Melo-de-Pinna 2000).

The organization of adventitious root secretory canals of Ianthopappus corymbosus differs from that in Richterago spp. (Melo-de-Pinna 2000), since epithelial cells are well differentiated from remaining cortical cells. This observation supports Roque \& Hind (2001) proposal to create a new genus, based on a cladistic analysis that used morphological and pollinical characters.

The existence of an endodermis in all organs of Ianthopappus corymbosus shows, just like in Richterago (Melo-de-Pinna 2000), the continuity of plant tissues, and emphasizes the definition of endodermis as the most internal cortex layer, originated from the ground meristem, which can be differentiated as an amyliferous sheath, with Casparian strips, or not differentiated at all, just like a parenchyma sheath. Some studies on Asteraceae report the existence of endodermis in the stem, with such layer differentiated with Casparian strips (Hoehne et al. 1952) or as an amyliferous sheath (Melo-de-Pinna 2000). In histochemical studies on several differentiation phases in the endodermis, Van Fleet (1961) states that besides Casparian strips and amyloplasts, endodermal cells may also contain phenolic substances. The aerial stem of Ianthopappus corymbosus undergoes a phase in which endodermal cells contain phenolic substances. In roots and in rhizophore, from the leaf trace up to its passage to the leaf, the endodermis has Casparian strips, and is differentiated as an amyliferous sheath in leaves.

Still relating to the anatomy of adventitious root of I. corymbosus, another point to be emphasized is the occurrence of an epidermis made up of lignified cells, with thickened root hairs. According to Fahn (1974), in Gleditschia triacanthos, the hairs remain for a long time and have thickened walls. The author also mentions that root hair longevity is related to a small secondary thickening of the root and absence of periderm. In these cases, the thickened root hairs clearly correspond to the old (base) root regions, which is not the case in I. corymbosus, where hairs are thick from the very beginning. From functional viewpoint, it is hard to imagine how the passage of water and soil nutrients takes place, since all the epidermal cells are lignified and there are no passage cells, unlike the endodermis or the hypodermis of monocotyledons. The epidermis, even when protected by the root cap, does not contain root hairs with primary walls. Presumably, the water comes in through capillarity only, like the water that comes in by leaf trichomes, as observed by Sousa (1997) in Melastomataceae.

In roots of Ianthopappus corymbosus, mycorrhiza were found in hypodermis and inner cortex cells. Based on Fahn's (1990) and Mauseth's (1995) definition, the association between fungal hyphae and I. corymbosus roots is endomycorrhizal. This type of association was mentioned for Asteraceae species belonging to genera Vernonia (Sajo \& Menezes 1986a, b) and Lychnophora (Luque 1995).

Ianthopappus corymbosus underground system consists of rhizophore from which adventitious roots originate. So far, the presence of rhizophore in Brazilian species has been reported in Asteraceae (Menezes et al. 1979, Sajo \& Menezes 1986a, b), Dioscoreaceae (Rocha \& Menezes 1997), and Smilacaceae (Andreatta $\&$ Menezes 1999). In all the above studies, the authors describe the existence of an aerial stem system with vegetative and floral buds, and another underground system, with endogenous lateral buds which have been 
previously described for Dioscoreaceae by Teichman und Logischen et al. (1977). Ianthopappus corymbosus clearly contains both bud systems, one specialized in root development, and another originating aerial branches.

An anatomical comparison between the aerial stem of Ianthoppapus corymbosus and those of Richterago spp. clearly shows that these are two distinct groups, based on the presence of cortical vascular bundles in I. corymbosus only. According to Metcalfe \& Chalk (1950), some other species of Asteraceae have cortical vascular bundles, including species of the Mutisieae tribe.

Font Quer (1985) defines pericycle as "estrato o estratos celulares externos del cilindro central, entre los hacecillos conductores y la endodermis, tanto en la raíz como en el tallo", that is, cells found outside the vascular cylinder, between the conducting tissues and the endodermis, which appear in the root and in the stem. Strong evidence shows that in I. corymbosus the pericycle is located between the endodermis and the perimedullary tissue. A fact observed in I. corymbosus that reinforces the presence of pericycle cells between the vascular bundles is that after leaving leaf traces, parenchyma cells found between the bundles follow the trace, staying adjacent and inside the xylem during such displacement. Once inside the petiole, these cells become lignified and form pericycle fibers.

Robbins \& Ricket (1934) have described pericycle fibers in stems of Asteraceae representatives. In Ianthopappus corymbosus, pericycle fibers are present in aerial stem, in leaf traces and in leaf vascular units. This shows that sclerenchyma sheath in Asteraceae, described by several authors (Carlquist 1957, Anderson \& Creech 1975, Breitwieser 1993, Breitwieser \& Ward 1998) may consist of pericycle fibers, as observed in I. corymbosus and Richterago spp. (Melo-de-Pinna 2000). For Lychnophora species, Luque (1995) considered these fibers as belonging to primary phloem. However, in the same study, an ilustration of a cross-section of the stem shows the presence of a leaf trace with fibers inside endodermis, similarly to stem vascular bundles, suggesting that these fibers may also have been originated from the pericycle, and not from the phloem.

Considering Font Quer's (1985) pericycle definition, Fahn (1990) stated that this tissue keeps its meristematic traits, and Eames \& McDaniels (1947) pointed out that zone development, referred by him as secondary cambium zones in the stem, usually takes place from the pericycle. In Ianthopappus corymbosys it is evident that the interfascicular cambium is originated from the pericycle.

A leaf character that supports the taxonomic treatment proposed by Roque \& Hind (2001) is the presence in Ianthopappus corymbosus of non-glandular trichomes, different from those found in Richterago species which are filiform (Melo-de-Pinna 2000).

Breitwieser (1993) and Breitwieser \& Ward (1998), in studies on species of the Inuleae, established a relationship between mesophyll organization and epidermal cell size. In species with a bilateral mesophyll, the adaxial surface cells are larger than those found in the abaxial surface, although the same does not apply to those with dorsiventral mesophyll. The same feature was found in Ianthopappus corymbosus.

The results of this study, which clearly corroborate generic separation of Ianthopappus corymbosus from species of the genus Richterago, highlight the importance of anatomical data in plant taxonomy. This study also supports the idea of continuity of plant tissues because endodermis and pericycle are found in root, stem and leaf (Robbins \& Ricket 1934).

Acknowledgements - Author thanks Capes, CNPq and FAPESP for funding.

\section{References}

ANDERSON, L.C. \& CREECH, J.B. 1975. Comparative leaf anatomy of Solidago and related Asteraceae. American Journal of Botany 62:486-493.

ANDREATA, R.H.P. \& MENEZES, N.L. 1999. Morfoanatomia do embrião, desenvolvimento pós-seminal e origem do rizóforo de Smilax quinquenervia Vell. (Smilacaceae). Boletim de Botânica da Universidade de São Paulo 18:39-51.

BARNABAS, A.D. 1996. Casparian band-like structure in the root hypodermis of some aquatic angiosperms. Aquatic Botany 55:217-225.

BERLYN, G.P. \& MIKSCHE, J.P. 1976. Botanical microtechnique and cytochemistry. Iowa State University Press, Ames.

BREITWIESER, I. 1993. Comparative leaf anatomy of New Zealand and Tasmanian Inuleae (Compositae). Botanical Journal of the Linnean Society 111:183-209.

BREITWIESER, I. \& WARD, J. 1998. Leaf anatomy of Raoulia Hook f. (Compositae, Gnaphalieae). Botanical Journal of the Linnean Society 126:217- 235.

BREMER, K. 1994. Asteraceae-Cladistic \& Classification. Timber Press, Portland.

CARLQUIST, S. 1957. Leaf anatomy and ontogeny in Argyroxiphium and Wilkesia (Compositae). American Journal of Botany 44:696-705. 
COL, M. 1899. Quelques recherches sur l'appareil sécréteur des Composées. Journal de Botanique 13:234-252.

COL, M. 1901. Quelques recherches sur l'appareil sécréteur des Composées. Journal de Botanique 15:166-168.

COL, M. 1903. Recherches sur l'appareil sécréteur interne des Composées. Journal de Botanique 17:288-318.

COL, M. 1904. Recherches sur l'appareil sécréteur interne des Composées. Journal de Botanique 18:153-175.

EAMES, A.J. \& MACDANIELS, L.H. 1947. An Introduction to plant anatomy. $2^{\text {nd }}$ ed. McGraw-Hill Book Co., New York.

ESAU, K. 1960. Anatomy of seed plants. Wiley International Edition, New York.

FAHN, A. 1974. Plant anatomy. $3^{\text {rd }}$ ed. Pergamon Press, Oxford. FAHN, A. 1990. Plant anatomy. $4^{\text {th }}$ ed. Pergamon Press, Oxford. FONT QUER, P. 1985. Diccionario de Botánica. Editorial Labor, Barcelona.

HEYWOOD, V.H. 1978. Flowering plants of the world. Oxford University Press, Oxford.

HOEHNE, W., GROTTA, S.A. \& SCAVONE, O. 1952. Contribuição ao estudo morfológico e anatômico de Calea pinnatifida Banks. Anais da Faculdade de Farmácia e Odontologia da Universidade de São Paulo 10:9-33.

KRAUS, J.E., SOUSA, H.C., REZENDE, M.H., CASTRO, N.M., VECCHI, C. \& LUQUE, R. 1998. Astra blue and basic fucsin double staining of plant materials. Biotechnic \& Histochemistry 73:235-243.

JOHANSEN, D.A . 1940. Plant microtechnique. McGrawHill Book Co., New York.

LERSTEN, N.R. \& CURTIS, J.D. 1988. Secretory reservois (ducts) of two kinds in giantragweed (Ambrosia trifida; Asteraceae). American Journal of Botany 75:1313-1323.

LUQUE, R. 1995. Estudo morfoantômico em espécies de Lychnophora Mart. (Asteraceae) dos campos rupestres do Brasil. Tese de doutorado, Universidade de São Paulo, São Paulo.

LUQUE, R., N.L. MENEZES \& SEMIR, J. 1997. La función secretora de la endodermis de la raíz de especies de Lychnophora Mart. (Asteraceae). Plantula 1:221-228.

MAUSETH, J.D. 1995. Plant anatomy. Benjamin/Cumming Publising Company, Menlo Park.

MELO-DE-PINNA, G.F.A. 2000. Anatomia dos órgãos vegetativos dos gêneros Richterago Kuntze e Ianthopappus Roque \& D.J.N. Hind (MutisieaeAsteraceae). Tese de doutorado, Universidade de São Paulo, São Paulo.

MENEZES, N.L., MÜLLER, C. \& SAJO, M.G. 1979. Um novo e peculiar tipo de sistema subterrâneo em espécies de Vernonia da Serra do Cipó (Minas Gerais, Brasil). Boletim de Botânica da Universidade de São Paulo 7:33-38.

METCALFE, C.R. \& CHALK, L. 1950. Anatomy of the dicotyledons: leaves, stem and wood in relation to taxonomy with notes on economic uses. Clarendon Press, London. v. 2.

MUELLER, R.J. 1991. Identification of procambium in the primary root of Trifolium pratense (Fabaceae). American Journal of Botany 78:53-62.
ROBBINS, W.J. \& RICKET, H.W. 1934. Botany. $2^{\text {nd }}$ ed. D. Van Nostrand Company, New York.

ROCHA, D.C. \& MENEZES, N.L. 1997. O sistema subterrâneo de Dioscorea kunthiana Uline ex R. Knuth (Dioscoreaceae). Boletim de Botânica da Universidade de São Paulo 16:1-11

ROQUE, N. \& HIND, D.J.N. 2001. Ianthopappus a new genus of the tribe Mutisieae (Compositae). Novon 11:96-100

SAJO, M.G. \& MENEZES, N.L. 1986a. Anatomia do rizóforo de espécies de Vernonia Screb. (Compositae) da Serra do Cipó, MG. Revista Brasileira de Biologia 46:189-196.

SAJO, M.G. \& MENEZES, N.L. 1986b. Origem e crescimento do rizóforo em espécies de Vernonia Screb. (Compositae), da Serra do Cipó, MG. Revista Brasileira de Biologia 46:197-202.

SASS, J.E. 1951. Botanical microtechnique. Iowa State College Press, Ames.

SEAGO, J.L.JR., PETERSON, C.A. \& ENSTONE, D.E. 1999. Cortical ontogeny in roots of the aquatic plant, Hydrocharis morsus-ranae L. Canadian Journal of Botany 77:113-121.

SEAGO, J.L.JR. \& SCHOLEY, A. 1999. Development of the endodermis and hypodermis of Typha glauca Gord. and Typha angustifolia L. roots. Canadian Journal of Botany 77:122-134.

SOLEREDER, H. 1908. Systematic anatomy of dicotyledons. Clarendon Press, Oxford.

SOUSA, H.C. 1997. Estudo comparativo de adaptações anatômicas em órgãos vegetativos de espécies de Lavoisiera DC. (Melastomataceae) da Serra do Cipó, MG. Tese de doutorado, Universidade de São Paulo, São Paulo.

TEICHMAN UND LOGISCHEN, I., ROBBERTSE, P.J. \& VAN DER SHIJF. 1977. The subterranean organs of Dioscorea cotinifolia Kunth: 1. Germination, development, morphology and vegetative reproduction of the tuberous swollen and cilindical intermediary organs. Journal of Society African of Botany 43:41-56.

TETLEY, U. 1925. The secretory system of the roots of the Compositae. The New Phytologist 24:138-161.

TRIEBEL, R. 1885. Ueber Oelbehälter in Wurzeln von Compositen. Nova Acta der Leopold-Carol. Deutschen Akademie der Naturforscher Band 1:1-45.

VAN FLEET, D.S. 1961. Histochemistry and function of the endodermis. Botanical Review 27:165-220.

WILLIAMS, B.C. 1947. The structure of the meristematic root tip and origin of the primary tissues in the roots of vascular plants. American Journal of Botany 34:455-462.

WILLIAMS, B.C. 1954. Observations on intercellular canals in root tips with special reference to the Compositae. American Journal of Botany 41:104-106. 